\title{
Parametri metaboličkog profilla krvi krava u razdoblju zasušenja
}

\author{
A. Ćutuk ${ }^{*}$, A. Hrković-Porobija, B. Čengić, E. Šaljić, L. Velić i A. Ajanović
}

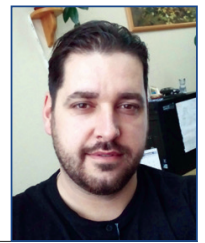

\section{Sažetak}

Metabolizam visokomliječnih krava, obzirom na njihovu genetsku predispoziciju za visoku proizvodnju mlijeka s jedne i reproduktivnih zahtjeva $\mathrm{s}$ druge strane, često je opterećen te izložen promjenama koje za posljedicu mogu imati poremećaj funkcionalnog stanja pojedinih organa, a najčešće jetre i genitalnih organa. Fiziološke vrijednosti biokemijskih parametara krvi krava, koje nude različiti izvori, često znaju znatno varirati. $U$ tom smislu, osobito su interesantni parametri metaboličkog profila u muznih krava, koji imaju višestruko značenje: od pokazatelja hranidbenog statusa i uvjeta držanja životinja do pokazatelja kliničkih bolesti. Cilj je ovog rada bio ustvrditi koncentraciju nekih biokemijskih parametara u krvnoj plazmi krava holštajnfrizijske pasmine tijekom perioda zasušenja. Ispitivanja koncentracije pojedinih sastojaka u krvnoj plazmi radi određivanja metaboličkog

profila krava važna su, ne samo za postavljanje objektivne dijagnoze i određivanje težine poremećaja u životinja $s$ izraženim simptomima, već i u prevenciji i rasvjetljavanju mehanizama nastanka novih, metaboličkih i drugih bolesti. Istraživanjem je obuhvaćeno ukupno 46 krava u zasušenju holštajn-frizijske pasmine iz dva farmska uzgoja. Istraženo

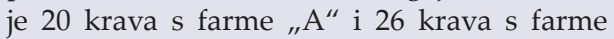
„B“. U krvnoj plazmi su spektrofotometrijski određivane vrijednosti parametara koncentracija: glukoze, ukupnih proteina, albumina, kolesterola, triglicerida, bilirubina i ureje. Na temelju rezultata našeg istraživanja, zaključili smo da su krvni parametri koje smo pratili adekvatni za praćenje funkcionalnog stanja jetre i metabolizma u krava, a koji mogu biti od koristi i u procjeni očekivane dužine servis perioda.

Ključne riječi: krave, krv, metabolički profil, zasušenje

\section{Uvod}

Suvremeni način uzgoja, tehnologija držanja i iskorištavanje visokomliječnih krava usmjereni su na neprekidno povećanje proizvodnje mlijeka i plodnosti

(Samardžija i sur., 2008., Hadžimusić i Hrković-Porobija., 2018., Szenci i sur., 2018., Kovacs i sur., 2020.). Međutim, takva proizvodnja zahtijeva i neophodnu

Dr. sc. Amel ĆUTUK*, dr. med. vet., izvanredni profesor, Katedra za Ambulantnu Kliniku, (dopisni autor, e-mail: amel.cutuk@vfs.unsa.ba), dr. sc. Amina HRKOVIĆ-POROBIJA, dr. med. vet., izvanredna profesorica, dr. sc. Benjamin ČENGIĆ, dr. med. vet., izvanredni profesor, dr. sc. Ermin ŠALJIĆ, dr. med. vet., izvanredni profesor, dr. sc. Lejla VELIĆ, dr. med. vet., izvanredna profesorica, dr. sc. Atifa AJANOVIĆ, dr. med. vet., izvanredna profesorica, Univerzitet u Sarajevu, Veterinarski fakultet, Sarajevo, Bosna i Hercegovina 
metaboličku prilagodbu organizma, kako bi se $u$ kontinuitetu osigurale neophodne količine hranjivih tvari za potrebe funkcioniranja mliječne žlijezde (Kočila i sur., 2013., Turk i sur., 2016.a). Ispitivanje metaboličkog profila, postupka dijagnostike zdravstvenog stanja visoko produktivnih krava, koristi se više godina (Folnožić i sur., 2016., Aladrović i sur., 2018.). Određivanje metaboličkog profila krava omogućava prepoznavanje trenutačnog hranidbenog i zdravstvenog stanja životinje (Aladrović i sur., 2018., Đuričić i sur., 2020.). Dobiveni podatci omogućavaju dokazivanje sposobnosti mliječnih krava za održavanje sastava krvi u fiziološkim granicama, pod različitim uvjetima držanja, hranidbe, produkcije, reprodukcije te na vrijeme ukazuju na eventualne poremećaje zdravlja.

Najkritičnije razdoblje

$\mathrm{za}$

metabolizam visokoproduktivnih krava je prijelaz iz razdoblja zasušenja $u$ fazu rane laktacije (Turk i sur., 2016.b, Folnožić i sur., 2019.a,b). Zasušenje krava predstavlja kratko razdoblje, između dvije laktacije, a koje $u$ prosjeku traje od 40 do 60 dana i predstavlja veoma važan period u pripremi mliječnih krava za sljedeću laktaciju (Maćešić i sur., 2012.). Literaturni podatci temeljeni na dugogodišnjim analizama, pokazuju da se gubitci u proizvodnji kreću u rasponu od 10 do $38 \%$, ukoliko se razdoblje zasušenja smanji ili u potpunosti izostavi, tijekom proizvodno-reproduktivnog ciklusa krava (Bachman i Schairer, 2003., Annen i sur., 2004.). Tradicionalno se misli da je idealno vrijeme trajanja razdoblja zasušenja između 50 do 60 dana, u kojem će životinja imati dovoljno vremena za odmor organizama i mliječne žlijezde te da u sljedećoj laktaciji može davati maksimalnu količinu mlijeka i u optimalnom vremenskom razdoblju ući $\mathrm{u}$ novi reproduktivni ciklus (Maćešić i sur., 2012.).

Značenje razdoblja zasušenja u krava ogleda se i kroz involuciju mliječne žlijezde koja se događa u tom razdoblju, jer tijekom razdoblja zasušenja, u krava dolazi do zamjene starih mamarnih epitelnih stanica novima (Rastani i sur., 2005.).

Uzimajući u obzir da mamarna involucija u preživača nije toliko opsežna kao u glodavaca (Li i sur., 1999.), većina se autora slaže da je optimalna dužina trajanja razdoblja zasušenja u krava 40 dana (Annen i sur., 2004., Rastani i sur., 2005.).

Energetski metabolizam u mliječnih krava zbog njegove važnosti i učestalosti poremećaja u zadnjim stadijima gravidnosti (razdoblje zasušenja) i ranoj laktaciji te ekonomskih šteta koje ti poremećaji mogu prouzročiti u govedarstvu predmet je brojnih studija. Upravo ekonomsko značenje, ukazuje na potrebu istraživanja biokemijskih parametara u krvi tijekom navedenih razdoblja, jer se na osnovu rezultata istraživanja biokemijskih parametara može primijeniti pravovremena korekcija hranidbe i poduzeti ostale preventivne mjere $u$ cilju suzbijanja navedenih šteta (Kočila i sur., 2009., Folnožić i sur. 2015.). Stoga je cilj ovog istraživanja bio ustvrditi koncentraciju nekih biokemijskih parametara u krvnoj plazmi krava holštajn-frizijske pasmine tijekom razdoblja zasušenja.

\section{Materijali i metode}

Istraživanjem je obuhvaćeno ukupno 46 krava u zasušenju holštajn-frizijske pasmine iz dva farmska uzgoja u razdblju između treće i osme laktacije, s prosječnom proizvodnjom mlijeka od oko $6.350 \mathrm{~kg}$ godišnje. Ispitivana grla su bila osrednjeg gojidbenog stanja, odnosno kondicije. Istraženo je 20 krava s farme "A" i 26 krava s farme "B“. Krave su držane na dva načina; farma "A" sustav držanja na vezu u štalama zatvorenog tipa i farma "B" polu-slobodni sustav držanja. Hranidba krava bila je 
neujednačena i varirala je $\mathrm{u}$ pojedinim sezonama količinski i u kvaliteti. Zimski obrok uglavnom je bio baziran na sijenu i kukuruznoj silaži uz dodatak koncentrata, dok je ljetnu hranidbu uglavnom činila zelena masa uz adekvatnu dopunu drugim hranjivim tvarima. Napajanje je vršeno automatskim pojilicama „ad libitum" $^{\prime}$. Eksperimentalne krave bile su podijeljene $\mathrm{u}$ dvije skupine na osnovu dužine servisnog razdoblja. Prvu skupinu su činile krave koje su imale servisno razdoblje do 80 dana i drugu skupinu krave sa servisnim razdobljem preko 80 dana. (ovo nije prikazano nigdje sve do zaključaka i treba izbaciti). Rezultati su obrađivani i prikazani skupno za sve krave, kao i za obje navedene skupine, kako je i prikazano na grafikonima.

Uzorci krvi su uzimani iz v.coccigaeae iglama promjera $\mathrm{G} 20$, u heparinizirane vakutaner epruvete od $a 5 \mathrm{~mL}$. Od svake životinje uzimana je krv u dvije epruvete. Neposredno po uzorkovanju koje je vršenou posljednjem mjesecu gravidnosti, određena je koncentracija glukoze u krvi (Accu - check easy metodom). Krv je transportirana $\mathrm{u}$ prijenosnom hladnjaku na temperaturi od $+4{ }^{\circ} \mathrm{C}$ do laboratorija Katedre za hemiju, biokemiju i fiziologiju Veterinarskog fakulteta u Sarajevu, BiH. Odmah po dolasku u laborartorij krv je centrifugirana na 4000 okretaja u trajanju od 15 min (LC 320) u cilju izdvajanja plazme.

U krvnoj plazmi su određivane koncentracije sljedećih parametara: glukoze, ukupnih proteina, albumina, kolesterola, triglicerida, bilirubina i ureje. Svi navedeni parametri su određivani korištenjem spektrofotometra „Beckmann DU-64 UV/VIS“. Korišteni su komercijalni kitovi, proizvođača „Human", Njemačka. Obrada dobivenih rezultata za dvije ispitivane skupine krava izvršena je dvosmjernim "t $\mathrm{t}^{\prime}$ testom za nezavisne uzorke na tri razine statističke značajnosti: ${ }^{*}(P<0,05)$, ${ }^{* *}(P<0,01),{ }^{* * *}(P<0,001)$.
Statistički značajne razlike između različitih farmi prikazane su grafički pomoću zvijezdica $\left(^{*}\right)$, a unutar istih farmi pomoću kružića $\left({ }^{\circ}\right)$. Za ispitivanje ovisnosti i povezanosti između odabranih parametara određeni su korelacijski koeficijenti. Sva obrada podataka izvršena je pomoću programa MS Excel 2003. Sve vrijednosti na grafikonima predstavljaju srednju vrijednost i pogrešku srednje vrijednosti $(\overline{\mathrm{x}} \pm \mathrm{S} \overline{\mathrm{x}})$. Oznake Ia, IIa, IIIa, predstavljaju različite dužine trajanja servisnog razdoblja, gdje je:

Ia = Sve ispitivane krave - prosječno servisno razdoblje; farma "A" 144 dana, farma "B" 104,4 dana.

IIa = Skupina krava sa servisim razdobljem $\leq 80$ dana; farma " $\mathrm{A}$ " 71,8 dana, farma "B" 69,5 dana.

IIIa = Skupina krava sa servisnim razdobljem > 80 dana; farma " $\mathrm{A}$ " 174,4 dana, farma "B" 148,8 dana.

\section{Rezultati i rasprava}

Dobivene vrijednosti koncentracije glukozeukrvikojesmoispitivalinadvjema farmama pri različitim vremenskim trajanjima servisnog razdoblja nalazile su se $\mathrm{u}$ fiziološkim granicama (grafikon 1.). Najveća koncentracija glukoze

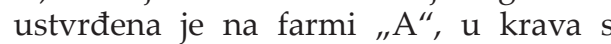
produženim servisnim razdobljem, a najniža također na farmi ",A $\mathrm{A}^{\prime}$, kod krava s kraćim servisnim razdobljem. Iako su se srednje vrijednosti koncetracije glukoze razlikovale $u$ ispitanih životinja

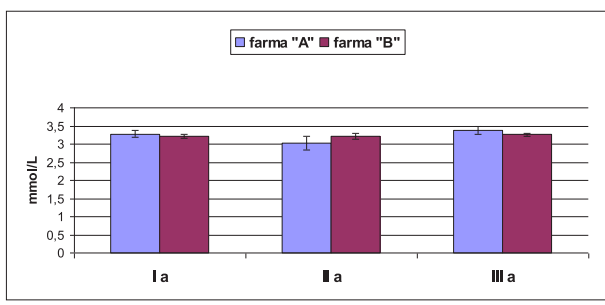

Grafikon 1. Koncentracija glukoze (mmol/L) u krvi zasušenih krava, kod različitog trajanja servinog razdoblja 
na dvjema farmama u odnosu na različito trajanje servisnog razdoblja, statističkim testiranjem nije ustvrđena signifikantnost razlika, kao niti testiranjem ispitivanih životinja unutar istih farmi.

Dobivene su vrijednosti ukupnog proteina $\mathrm{u}$ svih analiziranih kategorija krava, na farmi "A $\mathrm{A}$ " i na farmi „B“ bile više $u$ odnosu na fiziološki prosjek. Najveća i najniža vrijednost koncetracije ukupnih proteina ustanovljena je na farmi "B“. Tako je u krava čiji je servino razdoblje bilo duže od 80 dana izmjerena najveća koncetracija, dok je najniža koncetracija ustvrđena u krava sa servisnim razdobljem kraćim od 80 dana. Statističkim testiranjem dobivenih vrijednosti ukupnog proteina nije ustvrđena statistički značajna razlika, kako između različitih, tako i unutar istih farmi.

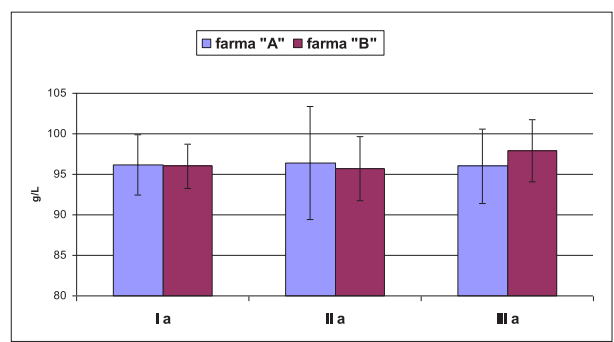

Grafikon 2. Koncentracija ukupnih proteina (g/L) u plazmi zasušenih krava kod različitog trajanja servisnog razdoblja

Dobivene srednje vrijednosti koncentracije albumina na obje farme, pokazale su da krave s kraćim servisnim razdobljem imaju nešto veće vrijednosti $\mathrm{u}$ odnosu na krave s dužim servisnim razdobljem (grafikon 3.). Razlike srednjih vrijednosti albumina unutar ispitivanih kategorija bile su male i nisu bile statistički značajne.

Koncentracija kolesterola u krvnoj plazmi ispitivanih krava bila je $u$ fiziološkim okvirima za datu kategoriju životinja (grafikon 4.). Prosječna

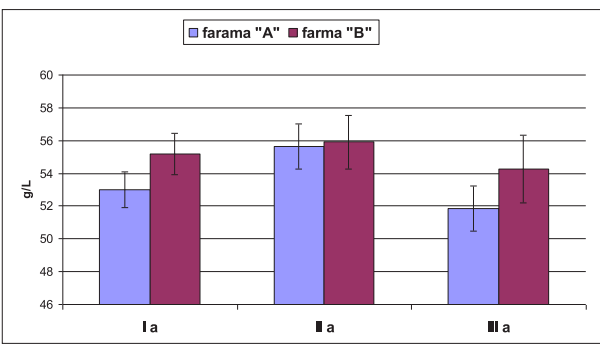

Grafikon 3. Koncentracija albumina $(\mathrm{g} / \mathrm{L}) \mathrm{u}$ plazmi zasušenih krava, kod različitog trajanja servisnog razdoblja

koncentracija kolesterola na farmi "A $\mathrm{A}^{\prime}$ te koncetracija kolesterola $\mathrm{u}$ krava sa skraćenim i produženim servisnim razdobljem na istoj farmi, bile su više $\mathrm{u}$ odnosu na prosječne vrijednosti dobivene na farmi „, $\mathrm{B}$ “ za obje kategorije krava. Unutar kategorija razlike su bile minimalne i nisu bile statistički značajne.

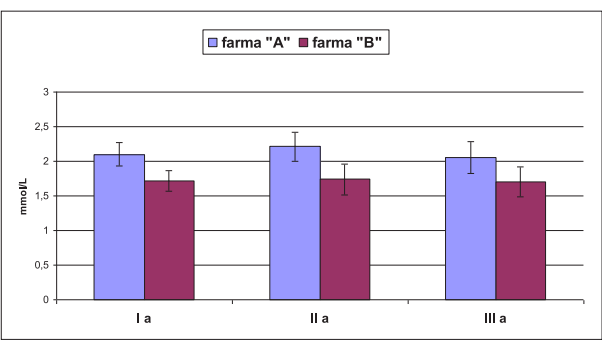

Grafikon 4. Koncentracija kolesterola (mmol/L) u plazmi zasušenih krava, kod različitog trajanja servisnog razdoblja

Rezultati ispitivanja koncetracije triglicerida na obje farme pokazali su izvjesne razlike između pojedinih kategorija ispitivanih zasušenih krava (grafikon 5.). Veće vrijednosti triglicerida ustvrđene su u krava na farmi „, $\mathrm{B}^{\text {“ }}$ za obje ispitivane kategorije, $\mathrm{u}$ odnosu na krave s farme "A $\mathrm{A}$, ali razlike unutar kategorija nisu bile statistički značajne unutar istih, niti između različitih farmi.

Prosječne vrijednosti ukupnog bilirubina $\mathrm{u}$ ispitivanih životinja na obje farme su se razlikovale, ali su ipak 


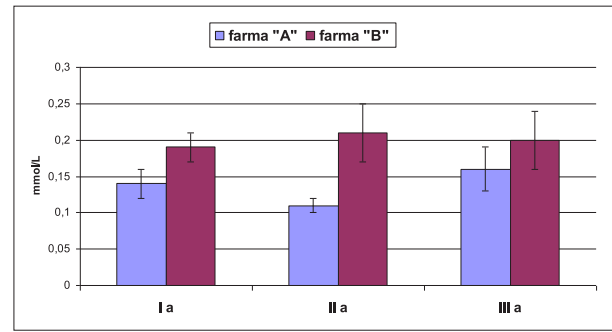

Grafikon 5. Koncentracija triglicerida (mmol/L) u plazmi zasušenih krava, kod različitog trajanja servisnog razdoblja

bile u fiziološkim vrijednostima. Veća koncentracije bilirubina ustvrđena je u krava koje su imale servisno razdoblje do 80 dana i na jednoj i na drugoj farmi, u odnosu na krave s produženim servisnim razdobljem. Statističkim testiranjem ni u jednoj skupini krava nisu utvrđene statistički značajne razlike dobivenih vrijednosti ukupnog bilirubina, kako unutar istih tako i između različitih farmi.

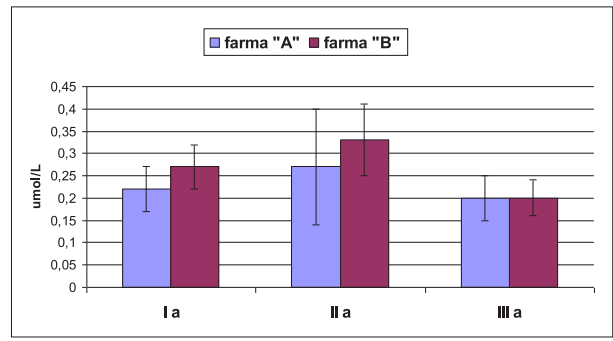

Grafikon 6. Koncentracija ukupnog bilirubina ( $\mu \mathrm{mol} / \mathrm{L}$ ) u plazmi zasušenih krava, kod različitog trajanja servisnog razdoblja

Ustvrđene prosječne vrijednosti koncentracije ureje u plazmi ispitivanih krava, bile su stabilne i gotovo ujednačene unutar istih farmi u različitih kategorija krava (grafikon 7.). Za životinje s farme „B" kod različitih kategorija uočena je signifikantno veća koncentracija ureje u odnosu na krave s farme "A", zatim u krava sa skraćenim servisnim razdobljem $(P<0,05)$ te $\mathrm{u}$ krava $\mathrm{s}$ produženim servisni razdobljem $(P<0,001)$. Isto tako, statistički značajna razlika postojala je i kad se uspoređuju sve ispitivane krave na obje farme $\left({ }_{,} \mathrm{A}^{\prime \prime} \mathrm{i}, \mathrm{B}^{\prime \prime}\right)$. Statističkim testiranjima dobivenih vrijednosti koncentracije ureje unutar istih farmi nije uočena statistički značajna razlika.

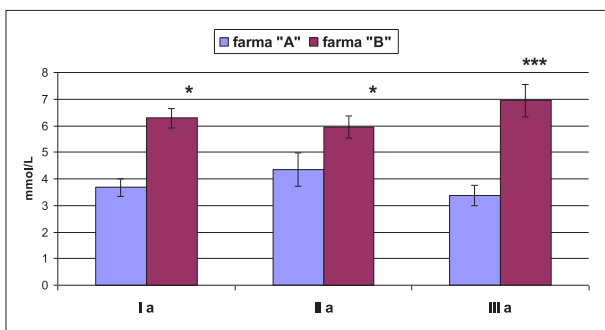

Grafikon 7. Koncentracija uree (mmol/L) u plazmi zasušenih krava, kod različitog trajanja servisnog razdoblja

* = statistički značajna razlika $(P<0,05)$ između različitih farmi

*** = statistički veoma visoko značajna razlika $(P<0,001)$ između različitih farmi

Prema literaturnim podatcima referentne prosječne vrijednosti koncentracije glukoze (grafikon 1.) u krvi krava kreću se $\mathrm{u}$ rasponu od 2,3 do 4,23 $\mathrm{mmol} / \mathrm{L}$ (Kaneko, 1997., Yang i sur., 2019.). U našem istraživanju ustvrdili smo da je koncentracija glukoze $u$ zadnjem mjesecu gravidnosti bila $u$ rasponu od 3,03 do 3,38 $\mathrm{mmol} / \mathrm{L}$. Isto tako iz dobivenih rezultata istraživanja uočljiva je jasna razlika u vrijednostima koncetracija u krava s kraćim servisnim razdobljem periodom $u$ odnosu na krave s dužim servis periodom. Međutim, bez obzira na prisutna variranja i dobivene oscilacije $u$ pogledu vrijednosti koncetracije glukoze u našim istraživanjima, treba naglasiti da su se one ipak nalazile $u$ fiziološkim okvirima. Javlja se dvojba između referentnih vrijednosti za navedeni parametar, je li u pitanju smanjenje/povećanje koncetracije glukoze u krvi ispitivanih kategorija krava, posljedica njenog nedovoljnog/prekomjernog unošenja $u$ organizam putem hranidbe, ili je razlog tome poremećaj metabolizma ugljikohidrata. 
Ukupni serumski proteini i albumini su pokazatelji produktivnog i funkcionalnog stanja jetre životinja. Dobivene vrijednosti koncentracije ukupnih proteina (grafikon 2.) u našim istraživanjima bile su veće i razlikovale su se od navoda većine autora. Prema istraživanju koje su proveli Kaneko i sur. (1997.), referentne se vrijednosti za ukupni protein kreću u rasponu 67,4$76,62 \mathrm{~g} / \mathrm{L}$, a prema istraživanju Radostits i sur. (2000.) one iznose 57-81 g/L. Prema navodima Merck Veterinary Manual (2003.) vrijednosti ukupnog proteina iznose između 62-82 g/L. Šamanc i sur. (2005.) provodio je istraživanja na većem broju životinja, pri čemu je ustvrdio da se koncentracija ukupnih proteina smanjuje $\mathrm{u}$ zadnjem mjesecu gravidnosti u odnosu na prethodne mjesece. Taj se umjeren pad nakon teljenja nastavlja i smatra se da je posljedica prelaska imunoglobulina iz krvi u "prvo" mlijeko-kolostrum. Do promjena $u$ koncentraciji ukupnih proteina, može doći i usljed promjena $\mathrm{u}$ koncentracijama proteinskih frakcija, kao i povećanja vrijednosti koncentracije ukupnih proteina i albumina u krvnom serumu, kao posljedica početka stvaranja kolostruma (Samanc i sur., 2005.).

Ova se oscilacija koncentracije proteina može objasniti hranidbom krava s jedne strane te veoma zahtjevnim fiziološkim stanjem - visoka gravidnost, s druge strane, kada dolazi do intenziviranja svih metaboličkih procesa u organizmu. Osim toga, karakteristike metabolizma $\mathrm{u}$ različitim stadijima gravidnosti utječu na koncentraciju ukupnih proteina $u$ krava te se tako s približavanjem partusa, povećava nivo $\gamma$-globulina, što se odražava na vrijednost ukupnih proteina (Weaver i sur., 2000.).

Srednje vrijednosti albumina (grafikon 3.) u našem istraživanju na obje farme bile su u rasponu od 51,8455,90 g/L u plazmi, odnosno ustvrđena je hiperalbuminemija $u$ odnosu na fiziološki prosjek. Kao referentne fiziološke vrijednosti albumina $u$ literaturi navode se vrijednosti od 2739 g/L (Kaneko i sur., 1997.). Ovakvo stanje organizma (hiperalbuminemija)is usually associated with dehydration and hypoalbuminaemia with liver-, kidney-, može, između ostalih čimbenika, biti povezano i s višim temperaturama tijekom ljeta, kada je i rađeno uzorkovanje krvi za analizu, odnosno da je u životinja u određenoj mjeri, možda bila prisutna i dehidracija organizma. Sličnog mišljenja su Kaneko i sur. (1997.), koji su tijekom ljeta u krava ustvrdili hiperalbuminemiju. Hiperalbuminemija je uočena u krava unutar istih farmi, s tim da su krave sa servisnim razdobljem do 80 dana, imale više vrijednosti od krava s dužim servisnim razdobljem. Slično kao i za dobivene vrijednosti albumina, $\mathrm{u}$ ispitivanih krava unutar istih farmi, hiperproteinemija, i to većeg stupnja, ustvrđena je u krava na farmi "A", koje su imale servisno razdoblje do 80 dana, u odnosu na krave s dužim servis periodom.

S obzirom na prethodne konstatacije, jedini logičan zaključak koji se nameće u rezultatima našeg istraživanjajest pojava hiperproteinemije i hiperalbuminemije kao posljedica dehidracije organizma $\mathrm{u}$ ispitivanih krava. Uzimajući u obzir to da je uzorkovanje krvi rađeno $u$ ljetnom razdoblju, kada su vanjske temperature dosezale i do $35{ }^{\circ} \mathrm{C}$, moguće je da je i to doprinijelo nastanku hiperalbuminemije i hiperproteinemije, iako su obje farme raspolagale $\mathrm{s}$ automatskim pojilicama. S druge strane približavanjem partusa povećava se nivo $\gamma$-globulina, što se odražava na vrijednost ukupnih proteina $u$ krvi životinja, dok u periodu samog partusa, dolazi do pada vrijednosti ove proteinske frakcije, jer ona biva prenesena u kolostrum. Konačno, raznolika hranidba mogla je utjecati na dobivene, povišene vrijednosti za albumin $u$ ispitivanih životinja. 
U metabolizmu kolesterola (grafikon 4.) jetra igra najvažniju ulogu, iz razloga što ga ona sintetizira i esterifikuje (Hill i Andrews, 2000.). Prisustvo i koncentracija kolesterola $\mathrm{u}$ plazmi ispitivanih krava, imali su vrijednosti koje su se kretale u fiziološkim okvirima za danu vrstu i kategoriju životinja, a koje iznose 1,5$6,7 \mathrm{mmol} / \mathrm{L}$ (Ramadan i Harapin, 1998.). Radostits i sur. (2000.) navode fiziološki raspon od 1,0-5,6 mmol/L, a slično njima navodi Merck Veterinary manual (2003.) $\mathrm{s}$ rasponom od 1,6-5,0 $\mathrm{mmol} / \mathrm{L}$. Yokus i Cakir (2006.) su u svojim istraživanjima odredili vrijednost kolesterola u krava $u$ laktaciji i ona je iznosila 5,29 $\mathrm{mmol} / \mathrm{L}, \mathrm{u}$ razdoblju rane gravidnosti $5,54 \mathrm{mmol} / \mathrm{L}$, $\mathrm{u}$ razdoblju sredine gravidnosti 4,40 $\mathrm{mmol} / \mathrm{L} \mathrm{i} \mathrm{u} \mathrm{razdoblju} \mathrm{visoke} \mathrm{gravidnosti}$ $4,68 \mathrm{mmol} / \mathrm{L}$.

Naše istraživanje nije pokazalo statistički značajne razlike vrijednosti kolesterola u različitih kategorija ispitivanih krava na različitim farmama. Unutar iste farme zabilježene su povećane vrijednosti u krava sa servisnim razdobljem do 80 dana $\mathrm{u}$ odnosu na krave s dužim servisnim razdobljem. Vrijednosti za kolesterol $u$ našim istraživanjima nalazile su se $\mathrm{u}$ fiziološkim okvirima, ali su bile nešto snižene. U literaturi se navodi da je koncentracija kolesterola u prosjeku značajno smanjena u krvi krava s hepatopatijom i u vezi je sa stupnjem zamašćenja jetre, a promjene mogu da ukazuju na poremećaj funkcije jetre $u$ odnosu na smanjenu sintezu i izlučivanje kolesterola (Grumer, 1993.). Naše fiziološke, ali opet nešto snižene vrijednosti serumskog kolesterola, možemo povezati s velikim naporima kojima su izložene ispitivane životinje ili sa blagim oštećenjima jetre izazvanim parazitozama ili nekim drugim uzrocima. Isto tako smanjena i koncentracija kolesterola za vrijeme zasušenja krava, može biti prouzročena i povećanim zahtjevima fetusa za svoj rast i razvoj (Pysera i Opalka, 2000.), što treba imati u vidu prilikom interpretacije naših dobivenih rezultata.

Fiziološki, u zdravih životinja jetra je glavni organ $u$ kojem se neprestano razgrađuju i sintetiziraju trigliceridi (grafikon 5.). Vrijednosti triglicerida u krvnoj plazmi u krava prema većini autora, kreće se u rasponu od 0,17-0,51 $\mathrm{mmol} / \mathrm{L}$ (Ramadan i Harapin, 1998.). U našim istraživanjima koncentracija triglicerida u krvnoj plazmi svih 46 krava varirala je od 0,11-0,21 mmol/L, odnosno bili su nešto nižih vrijednosti u odnosu na vrijednosti koje iznose prethodna dva autora. Rezultati ispitivanja koncetracije triglicerida u krvnoj plazmi zasušenih krava na obje farme pokazivali su neznatne razlike između različitih kategorija krava. Hodžić i sur. (2006.) su u svojim istraživanjima ustvrdili gotovo indentične koncentracije za trigliceride, koje su također bile niže $\mathrm{u}$ odnosu na gore navedene autore.

$\mathrm{Na}$ osnovu naših rezultata, ovakav hipotrigliciridemijski nalaz $u$ krava $s$

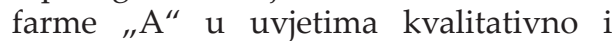
kvantitativno neuravnotežene hranidbe, posebice u uvjetima negativnog energetskog statusa, ukazuje na pojačanu lipomobilizaciju te poremećaj prijenosa masti između jetre i masnog tkiva, što dovodi do zadržavanja i nagomilavanja triglicerida $\mathrm{u}$ jetri. Isto tako ne treba zaboraviti činjenicu da intenzivni metabolizam mliječnih krava, koji se događa u periodu kasne gravidnosti i rane laktacije, očituje se intenzivnim promjenama koncentracija metabolita $\mathrm{u}$ krvi, naročito promjenama koncentracija lipidnih sastojaka krvi (Rukkwamsuk i sur., 1999.). Metabolička prilagodba na povećanje energetskih potreba tijekom kasne gravidnosti (razdoblje zasušenja), odražava se na metabolizam lipida, kroz povećanje njegove koncentracije $u$ razdoblju zasušenja i smanjenja tijekom puerperija.

Koncetracija bilirubina (grafikon 6.) u krvi se smatra važnim pokazateljem 
funkcionalnog stanja jetre. Fiziološke vrijednosti bilirubina u krava imaju široke varijacije. Meyer i sur. (1992.), kao referentne vrijednosti bilirubina navode raspon od 1,71-8,55 $\mu \mathrm{mol} / \mathrm{L}$. Rezultati našeg istraživanja pokazali su kretanje bilirubina $\mathrm{u}$ ispitivanoj plazmi $\mathrm{u}$ granicama od 0,20-0,33 $\mu \mathrm{mol} / \mathrm{L}$. Povećanje vrijednosti ukupnog bilirubina ukazuje na izraženi deficit energije, koji vodi do opterećenja funkcija jetre. Srednja vrijednost koncetracije ukupnog bilirubina tijekom našeg istraživanja na obje farme, bila je u fiziološkim granicama, iako je bila nešto niža u krava s farme ", $\mathrm{A}^{\prime}$, čija je dužina servisnog razdoblja trajala do 80 dana, $\mathrm{u}$ odnosu na krave $\mathrm{s}$ farme „B“. U krava čije je servisno razdoblje prelazio 80 dana, vrijednosti koncetracije ukupnog bilirubina i na jednoj i na drugoj farmi bile su identične. Smatra se da na stupanj bilirubinemije zdravih životinja najviše utječe gladovanje i žeđ pa se uočene razlike između dvije farme mogu objasniti dehidracijom životinja i smanjenjem apetita zbog visokih ljetnih temperatura, koje su bile na farmi „, $\mathrm{B}^{\prime \prime} \mathrm{u}$ periodu uzorkovanja krvi.

Istraživanja pokazuju da jetra može preraditi nekoliko puta veću količinu bilirubina od normalne, a da ne istroši mehanizam sprege, tako da samo visoke količine hemoglobina dovode do povećanja vrijednosti bilirubina u krvi.

Ureja (grafikon 7.) je dobar indikator količine unesenog dušika putem hrane, a čija se sinteza odigrava u jetri (Bijgaart, 2002.). U literaturi je dostupno više referentnih vrijednosti: $2,8-8,8 \mathrm{mmol} / \mathrm{L}$ (Meyer i sur. 1992.)), 7,1-10,7 mmol/L, 2,3$8,8 \mathrm{mmol} / \mathrm{L}$ (Merck Veterinary Manual, 2003.), 7,14-10,7 mmol/L (Kaneko, 2008.).

Koncentracije ureje koje smo mi ustvrdili na farmi "B“ pokazuju više vrijednosti za obje kategorije krava $u$ odnosu na te iste kategorije na farmi "A". Iako su se pojedinačne vrijednosti ureje nalazile u fiziološkim okvirima, treba istaknuti da su one u krava s farme
"A" $\mathrm{A}$ " bile dosta niže, što ukazuje na blago narušenu funkciju jetre $\mathrm{u}$ ureopoetskom ciklusu i eventualno zadržavanje i nagomilavanje manje količine amonijaka u krvi. Nizak nivo koncentracije ureje može se objasniti i iskorištavanjem ureje za sintezu proteina preko rumenohepatičnog puta $\mathrm{u}$ svrhu kompenzacije smanjenja njegove koncetracije u krvi krava (Campanile i sur., 1998.). Veće vrijednosti ureje u krava s farme " $\mathrm{B}$ " mogle bi se dovesti u vezu s ustvrđenim većim vrijednostima koncentracije ukupnih proteina $\mathrm{u}$ ispitivanoj plazmi. Moguće je i to da su obroci krava na farmi „B" bili bogatiji proteinima u odnosu na farmu „A" u razdoblju uzorkovanja krvi.

\section{Zaključci}

Koncetracije ispitivanih sastojaka u krvnoj plazmi; glukoze (puna krv), kolesterola, bilirubina, kalcija, fosfora, magnezija i uree bile su u skladu s fiziološkim okvirima koje navode većina citiranih autora, osim vrijednosti ukupnog proteina i albumina koje su bile znatno povišene.

Vrijednosti triglicerida $\mathrm{u}$ krava $\mathrm{s}$ različitim trajanjem servisnog razdoblja na farmi " $\mathrm{A}$ " bile su niže u odnosu na fiziološki prosjek.

$\mathrm{Na}$ farmi " $\mathrm{A}$ " krave koje su imale servisno razdoblje kraće od 80 dana, imale su nešto više vrijednosti kolesterola, bilirubina, kalcija, fosfora, magnezija i uree, $\mathrm{u}$ odnosu na krave sa servisnim razdobljem preko 80 dana. $\mathrm{Na}$ farmi „, $\mathrm{B}^{\prime \prime}$, krave sa servisnim razdobljem kraćim od 80 dana su imale pored prethodno navedenih parametara povećane još $i$ albumine i trigliceride, $u$ odnosu na grupu krava čije je servisno razdoblje bilo duže od 80 dana.

\section{Literatura}

1. ALADROVIĆ J., M. PAVKOVIĆ, B. BEER-LJUBIĆ, L. VRANKOVIĆ and Z. STOJEVIĆ (2018): 
Metabolic profile in Holstein dairy cow herd. Vet. stn. 49, 9-18. (In Croatian).

2. ANNEN, E. L., R. J. COLLIER, M. A. MCGUIRE, J. L. VICINI, J. M. BALLAM and M. J. LORMORE (2004): Effect of modified dry period lengths and bovine somatotropin on yield and composition of milk from dairy cows. J. Dairy Sci. 87, 3746-3761.

3. BACHMAN, K. C. and M. L. SCHAIRER (2003): Invited Review: Bovine Studies on Optimal Lengths of Dry Periods. J. Dairy Sci. 86, 3027-3037.

4. BIJGAART, V. D. H. (2002): New applications of mid-infrared spectroscopy for the analysis of milk and milk products. Bulletin of the IDF 383, 5-15.

5. CAMPANILE, G., C. DE FILIPPO, R. DI PALO, W. TACCONE and L. ZICARELLI (1998): Influence of dietary protein on urea levels in blood and milk of buffalo cows. Livest. Prod. Sci. 55, 135-143.

6. ĐURIČIĆ, D., B. BEER LJUBIĆ, S. VINCE, R.TURK, H. VALPOTIĆ, I. ŽURA ŽAJA, N. MAĆEŠIĆ, M. BENIĆ, I. GETZ and M. SAMARDŽIJA (2020): Effects of dietary clinoptilolite supplementation on $\beta$-hydroxybutirate serum level and milk fat to protein ratio during early lactation in HolsteinFriesian cows. Microporous Mesoporous Mater. 292, 109766, 4 doi:10.1016/j.micromeso.2019.109766

7. FOLNOŽIĆ, I., M. SAMARDŽIJA, D. ĐURIČIĆ, S. VINCE, S. PERKOV, S. JELUŠIĆ, H. VALPOTIĆ, B. BEER LJUBIĆ, M. LOJKIĆ, D. GRAČNER, I. ŽURA ŽAJA, N. MAĆEŠIĆ, J. GRIZELJ, T. DOBRANIĆ, G. REDŽEPI, Z. ŠOSTAR and R. TURK (2019a): Effects of in-feed clinoptilolite treatment on serum metabolic and antioxidative biomarkers and acute phase response in dairy cows during pregnancy and early lactation. Res. Vet. Sci. 127, 57-64.

8. FOLNOŽIĆ, I., D. ĐURIČIĆ, I. ŽURA ŽAJA, S. VINCE, S. PERKOV, R. TURK, H. VALPOTIĆ, D. GRAČNER, N. MAĆEŠIĆ, M. LOJKIĆ, M. KOVAČIĆ and M. SAMARDŽIJA (2019b): The influence of dietary clinoptilolite on blood serum mineral profile in dairy cows. Vet. arhiv 89, 447-462.

9. FOLNOŽIĆ, I., R. TURK, D. ĐURIČIĆ, S. VINCE, J. PLEADIN, Z. FLEGAR-MEŠTRIĆ, H. VALPOTIĆ, T. DOBRANIĆ, D. GRAČNER and M. SAMARDŽIJA (2015): Influence of Body Condition on Serum Metabolic Indicators of Lipid Mobilization and Oxidative Stress in Dairy Cows During the Transition Period. Reprod. Domest. Anim. 50, 910-917.

10. FOLNOŽIĆ, I., R. TURK, D. ĐURIČIĆ, S. VINCE, Z. FLEGAR-MEŠTRIĆ, P. SOBIECH, M. LOJKIĆ, H. VALPOTIĆ and M. SAMARDŽIJA (2016): The effect of parity on metabolic profile and resumption of ovarian cyclicity in dairy cows. Vet. arhiv 86, 641-653.

11. HADŽIMUSIĆ, N. and A. HRKOVIĆ POROBIJA (2018): Effects of seasonal and geographical variation on blood biochemistry parameters of dairy cows. Vet. stn. 49, 229-237. (In Croatian).

12. HILL, J. and A. H. ANDREWS (2000): The expectant dairy cow. Chalcombe publications. Welton.

13. HODŽIĆ, A., J. KRNIĆ, E. ŠALJIĆ, Ć. CRNKIĆ, E. PAŠIĆ JUHAS i A. HRKOVIĆ (2006): Distribucija frekvencija za parametre metaboličkog profila muznih krava sa BiH farmi. U: VIII savjetovanje iz kliničke patologije i terapije životinja; Neum, BiH.

14. KANEKO, J. J., W. HARVEY and J. H. M. BRUSS (1997): Clinical biochemistry of domestic animals. 4 issue. San Diego: Academic Press.

15. KANEKO, J. J. (1997): Carbohydrate Metabolism and Its Diseases. Pp. 45-81. In: Clinical biochemistry of domestic animals, $5^{\text {th }}$ ed. (Kaneko, J. J., J. W. Harvey, M. L. Bruss). Academic Press, San Diego, London, Boston, New York, Sydney, Tokyo, Toronto.

16. KANEKO, J. J. (2008): Carbohydrate Metabolism and Its Diseases. In: Kaneko, J. J., Harvey, J. W., Bruss, M. L., eds. Clinical biochemistry of domestic animals. $6^{\text {th }}$ edition. Academic Press, p. 64.

17. KOČILA, P., A. JANŽEK, D. GRAČNER, T. DOBRANIĆ, D. ĐURIČIĆ, N. PRVANOVIĆ, N. FILIPOVIĆ, G. GREGURIĆ GRAČNER, LJ. BEDRICA, F. MARKOVIĆ and M. SAMARDŽIJA (2013): Vergleich von Progesteronkonzentrationen, Energiebilanzkennwerten und körperlicher Verfassung bei Milchkühen mit verschiedener Milchleistung im Puerperium. Tierärztl. Umsch. 68, 266-274.

18. KOČILA, P., M. SAMARDŽIJA, T. DOBRANIĆ, D. TOMISLAV, D. GRAČNER, V. DOBRANIĆ, N. PRVANOVIĆ, Ž. ROMIĆ, N. FILIPOVIĆ, N. VUKOVIĆ and D. ĐURIČIĆ (2009): Einfluss der Energiebilanz auf die Reproduktionsfähigkeit von Holsteiner Kühen im Puerperium. Tierärztl. Umsch. 64, 471-477.

19. KOVÁCS, L. L. RÓZSA, M. PÁLFFY, P. HEJEL, W. BAUMGARTNER and O. SZENCI (2020): Subacute ruminal acidosis in dairy cows - physiological background, risk factors and diagnostic methods. Vet. stn. 51, 5-17.

20. LI, P., P. S. RUDLAND, G. L. FERNIGD M. B. C. FINCH and J. WILDE (1999): Modulation of mammary development and programmed cell death by frequency of milk removal in lactating goats. J. Physiol. 519, 885-900.

21. MAĆEŠIĆ, N., T. KARADJOLE, G. BAČIĆ, M. BENIĆ, M. KARADJOLE, S. VINCE, M. LIPAR and M. CERGOLJ (2012): Aetiology and prevalence of bovine intramammary infection at drying off. Vet. arhiv 82, 125-131.

22. MERCK VETERINARY MANUAL (2003): $8^{\text {th }}$ ed., Merck Co., Inc Whitehause Station, NJ, USA.

23. MEYER, J. D., H. E. COLES and J. L. RICH (1992): Veterinary Laboratory Medicine: Interpretation and Diagnosis. (1992): W.B. Saunders Company, Philadelphia.

24. PYSERA, B. and A. OPALKA (2000): The effect of gestation and lactation of dairy cows on lipid and lipoprotein patterns and composition in serum during winter and summer feeding. J. Anim. Feed Sci. 9, 411-424.

25. RADOSTITS, O. M., D. C. BLOOD and C. C. GAY (2000): Veterinary Medicine. A textbook of the diseases of cattle, sheep, goats and horses. $8^{\text {th }}$ ed. London. 
26. RAMADAN, P. i I. HARAPIN (1998): Interna klinička propedeutika domaćih životinja. Zagreb: Veterinarski fakultet.

27. RASTANI, R. R., R. R. GRUMMER, S. J. BERTICS, A. GUMEN, M. C. WILTBANK G. MASHEKD and M. C. SCHWAB (2005): Reducing dry period length to simplify feeding transition cows: Milk production, energy balance, and metabolic profiles. J. Dairy Sci. 88, 1004-1014.

28. RUKKWAMSUK, T., T. KRUIP and T. WENSING (1999): Relationship between overfeeding and overconditioning in the problems of high producing dairy cows during the postparturient period. Vet. Q. 21, 71-77.

29. SAMARDŽIJA, M., T. DOBRANIĆ, S. VINCE, V. DOBRANIĆ, J. GRIZELJ, M. KARADJOLE, D. GRAČNER, LJ. BEDRICA and Z. ŽVORC (2008): Einfluss der Milchleistung auf die Fruchtbarkeitsstörungen bei Kühen im Puerperium. Tierärtzl. Umsch. 63, 123-127.

30. SZENCI, O., Z. SZELÉNYI, L. LÉNÁRT, D. BUJÁK, L. KOVÁCS, L. F. KÉZÉR, B. HAN and A. HORVÁTH (2018): Importance of monitoring the peripartal period to increase reproductive performance in dairy cattle. Vet. stn. 49, 297-307.
31. ŠAMANC, H., Z. SINOVEC, M. ADAMAOVIĆ i G. GRUBIĆ (2005): Uloga ishrane u etiopatogenezi poremećaja metabolizma visoko mlečnih krava. 4. simpozijum "Ishrana, reprodukcija i zaštita zdravlja goveda", 3-20, 16.

32. TURK, R., I. FOLNOŽIĆ, D. ĐURIČIĆ, S. VINCE, Z. FLEGAR-MEŠTRIĆ, T. DOBRANIĆ, H. VALPOTIĆ and M. SAMARDŽIJA (2016a): Relationship between paraoxonase-1 activity and lipid mobilisation in transition dairy cows. Vet. arhiv 86, 601-612.

33. TURK, R., I. FOLNOŽIĆ, D. ĐURIČIĆ, S VINCE, Z. FLEGAR-MEŠTRIĆ, T. DOBRANIĆ, H. VALPOTIĆ and M. SAMARDŽIJA (2016b): Relationship between paraoxonase-1 activity and lipid mobilisation in transition dairy cows. Vet. arhiv 86, 601-612.

34. WEAVER, D. M., J. W. TYLER, D. C. VANMETRE, D. E. HOSTETLER and G. M. BARRINGTON (2000): Passive transfer of colostral immunoglobulins in calves. J. Vet. Inter. Med. 14, 569.

35. YANG, W., B. ZHANG, C. XU, H. ZHANG and C. XIA (2019): Effects of ketosis in dairy cows on blood biochemical parameters, milk yield and composition, and digestive capacity. J. Vet. Res. 63, 555-560.

\section{Parameters of the metabolic profile in cow blood during the dry period}

Amel ĆUTUK, DVM, PhD, Associate Professor, Amina HRKOVIĆ-POROBIJA, DVM, PhD, Associate Professor, Benjamin ČENGIĆ, DVM, PhD, Associate Professor, Ermin ŠALJIĆ, DVM, PhD, Associate Professor, Lejla VELIĆ, DVM, PhD, Associate Professor, Atifa AJANOVIĆ, DVM, PhD, Associate Professor, University of Sarajevo, Veterinary faculty, Sarajevo, Bosna and Herzegovina

Due to their genetic predisposition for high milk production on the one hand and reproductive demands on the other, the metabolism of high yield dairy cows is often overloaded and under various effects. This may result in the disorder of organ functions, particularly the liver and reproductive system. Physiological values of biochemical parameters in cow's blood may vary widely. The parameters of the metabolic profile in dairy cows have multiple significance, such as indicators of nutritional status and housing, and may also indicate clinical disorders. The aim of this study was to determine the concentrations of certain biochemical parameters in the blood plasma of HolsteinFriesian cows during the dry period. Assessment of the concentration of biochemical components in blood plasma to assess the metabolic profile is significant for diagnostics, determining the degree of disorders in animals with expressed symptoms, and in preventing metabolic and other diseases. In total, 46 cows were included in the study from two farms, with 20 cows from farm A and 26 cows from farm B. Blood plasma was tested using the spectrophotometry method to determine the concentrations of glucose, total protein, albumin, cholesterol, triglycerides, bilirubin and urea. Based on the results, it can be stated that the monitored blood parameters are adequate for screening the functional state of the liver and metabolism in cows, and can show the expected length of the service period.

Key words: cows; blood; metabolic profile; dry period 